${ }^{4}$ PETERSON, R. T. 1961. A field guide to western birds. (2nd Ed.), Houghton Mifflin, Boston.

${ }^{5}$ PETERSON, R. T., G. MOUNTFORT and 'P. A. D. HOLLOM. 1974. A field guide to the birds of Britain and Europe, 3rd Ed. Collins, London.

${ }^{6}$ POUGH, R. H. 1949. Audubon land bird guide. Doubleday, New York.

${ }^{7} \mathrm{POUGH}, \mathrm{R} . \mathrm{H}$. 1957. Audubon western bird guide. Doubleday, New York.

${ }^{8}$ REED, C. A. 1965 . North American birds eggs (Rev. Ed.). Dover, New York.

${ }^{9}$ ROBBINS, C. S., B. BRUUN and H. S. ZIM. 1966. Birds of North America. Golden Press, New York.

10UDVARDY, M. D. F. 1977. The Audubon Society field guide to North American birds - western region. Alfred A. Knopf, New York.

\title{
NINETEENTH ANNUAL NESTBOX REPORT FROM BRANDON, MANITOBA
}

MRS. JOHN LANE, 1701 Lorne Avenue, Brandon, Manitoba, R7A 0W2, and MAMIE MCCOWAN, BARBARA ROBINSON, HAZEL PATMORE and LINDA MUZYKA.

In 1979 the nestbox project started by the late Dr. John Lane was again carried on by the "Friends of the Bluebirds". This group held two meetings at the home of the coordinator, Mrs. John Lane.

At the spring meeting, plans were made for the 1979 season. Mrs. Lane welcomed the new members who had responded to an article "Bluebirds in South Western Manitoba", published in the March issue of "This is Westman", and to slide presentations. Among these new Friends were young families, senior citizens and the Forrest 4-H Girls' Conservation Group. Some new members have made nest boxes using the Junior Birders' pattern. At this meeting Mrs. Lane also gave a report on the first Annual Meeting of the North American Bluebird Society held in Maryland, U.S.A., 11-12
November 1978. During the fall meeting, reports were presented and experiences discussed.

In 1979, 170 nest boxes were set out, bringing the total since the start of the project in 1959 to 5,010. It will be understood that a goodly number of this total are not now in place due to the effects of time, weather and interference. A supply of boxes for replacements and new nestlines was maintained by John Plum and Walter Forsyth, who merit much thanks.

Mr. and Mrs. Perry Hopkins, Hartney area, filled out the North American Bluebird Society's "23 nest record data". The Hopkins also reported two adjacent boxes infested by black flies (Simulium venustum). In these boxes a total of 11 young Mountain Bluebirds were found dead. 
TABLE 1 - Occupancy in Nest Boxes, 1979.

Occupant

Mountain Bluebirds

Eastern Bluebirds

Bluebirds not identified as to species

Tree Swallows

House Sparrows

House Wrens

Mice

Squirrels

Chipmunk

Noticeable numbers of dead bluebirds and Tree Swallows were noted through the season by various observers. It has been suggested that the extremely hot weather was a factor in this high mortality.

Mr. Jim Spear, Russell, deplored the hot dry summer season but also in his report commented on the spring:

"The spring was late and cold and I feel quite a few birds did not survive the cold. On May 12, many nest boxes were just above the water line and one was covered with snow. It was a spring to remember."

Counting his maintenance and monitoring of 300 nest boxes in 1979, Mr. Spear says he has travelled 1,000 miles.

Eastern Bluebirds were recorded by only four observers: Barbara Robinson - 11 nestings; Mr. and Mrs. Perry Hopkins - 13 nestings; J. B. Thomas - one nesting, and Peter Sawatzky - one nesting. Data since the project was started show a substantial decrease in the use of our nest boxes by Eastern Bluebirds the past five years.

Barbara Robinson on the South Shilo line reported some unusual Mountain Bluebird nests. Nest box No. 238 had a built-over nest. On 10 June the lower nest had seven eggs. On 19 July the upper nest had five
Number of Nestings

459

26

14

773

99

65

9

8

1 eggs. On 3 September, while cleaning out nest box No. 238, Barbara found the lower nest had four unhatched eggs and the upper nest had all five eggs unhatched. Both these nests were laced with Cedar Waxwing feathers. Also Barbara observed that in nest box No. 863 a Mountain Bluebird had built a very neat nest with plant down on top and sides and a few small feathers woven in with the grass.

On 22 September, during fall maintenance of her nest boxes at the western junction of No. 351 highway and the Trans Canada highway, Barbara was delighted to see a flock of 25 Eastern Bluebirds in migration. Later, on the same day, between Tapley Siding and Camp Hughes on the C.P.R., Barbara saw several flocks of Mountain Bluebirds totalling 60 in numbers.

Substantiating the observation that new nestlines are usually occupied by Tree Swallows in the first year, 1979 reports show that the Forrest 4-H Girls' Conservation Group set up a new nestline of 19 boxes. Tree Swallows occupied 18 of them and one was vacant. Also, Dr. R. Rounds and family set out a new line of 24 boxes near Martinville, northeast of Brandon Hills. Twentytwo boxes were occupied by Tree Swallows and one by House Sparrows; one was vacant. 


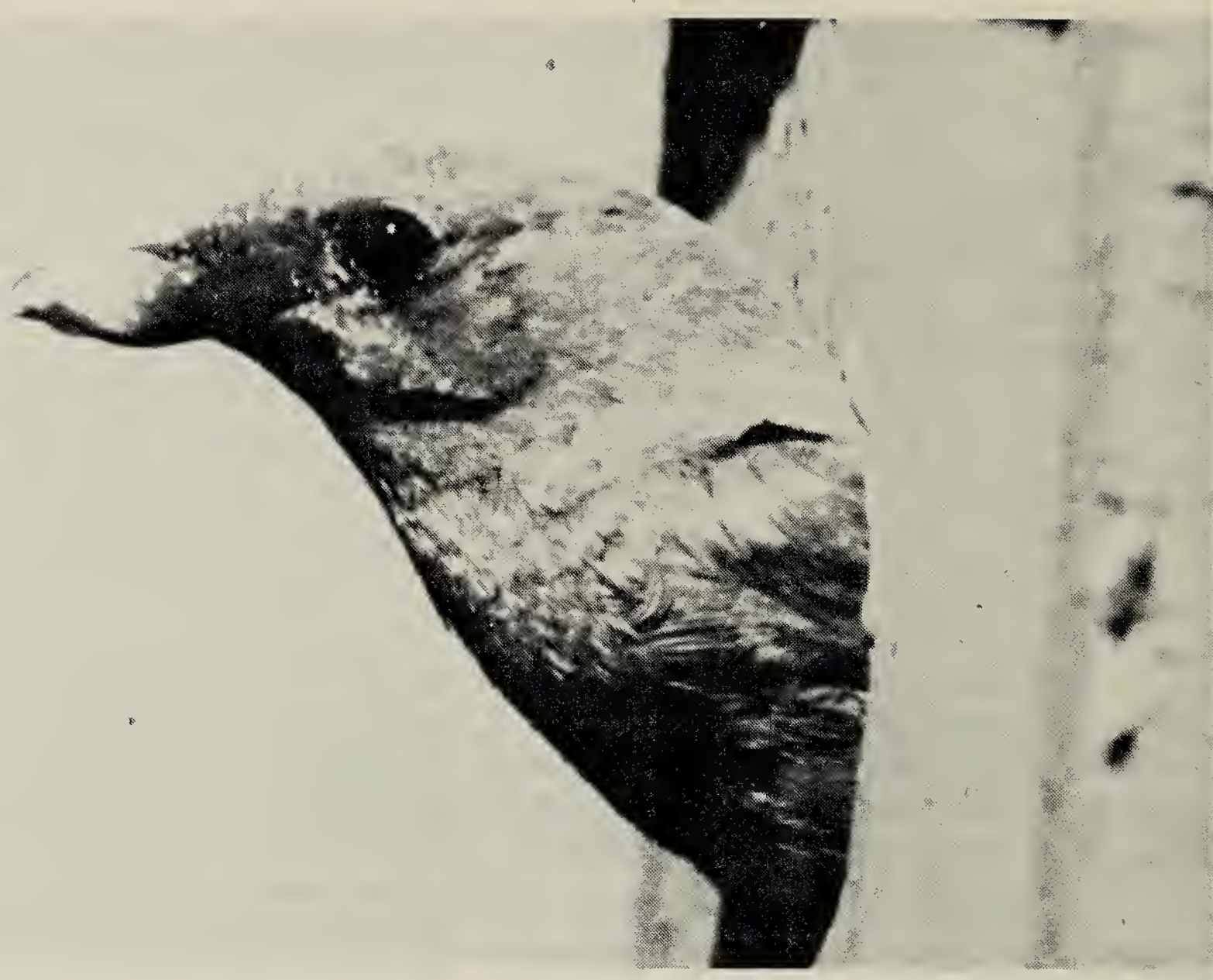

Mountain Bluebird.

Robert J. Long

This report was made possible through the work of the "Friends of the Bluebirds" from Boissevan - Mr. and Mrs. W. Moncur, Charles Reid; Carberry - Mr. and Mrs. Bob Anderson and family; Erickson - Mr. and Mrs. Keith Johnston, Melvin and Shirley, Mr. and Mrs. Arthur Koping; Forrest - Mrs. G. S. Parsons and 4H Girls Glenda Parsons, Sharon Hansen and Melanie Miller; Glenboro - Peter Sawatzky; Hartney - Mrs. and Mrs. Perry Hopkins, Mr. and Mrs. J. B. Thomas; Headingly - Mr. and Mrs. Carl Gompf, Jim and Jean Robson; Killarney - Mr. and Mrs. Lloyd Powell, Ruth Goerzen, Mrs. Vera Turner; Miami - Mr. and Mrs. Dale Robinson; Miniota - Mr. and Mrs. Jack Hanlin and grandchildren; Napinka - George T. Watson; Neepawa - Mrs. Fred Murray, Don and Ken, George Mossop; Newdale - Mr. and Mrs. Roy Everitt, Mr. and Mrs. Oran English; Ninette - Mr. and
Mrs. Monroe Wright; Oak Lake Rob and Heather Penner, Cathy and Winnie Sawatsky; Russell - Mr. and Mrs. Jim Spear; Shoal Lake - Cliff Findlay; Souris - Mr. and Mrs. Art Michie; Tilston - E. J. Jones; Virden - Mr. and Mrs. John Turton; Wawanesa - Mr. and Mrs. Ed Robinson; Winnipeg - Robert Burch; Brandon - Mrs. Barbara Robinson, John and Marion Robinson, Mamie, Helen and Margaret McCowan, Dick and Hazel Patmore, Daisy and Muriel Patmore, Barbara Robertson, Dr. and Mrs. Richard Rounds and family, Mr. John Plum, Mr. W. Forsyth, Linda Muzyka, Marlene Brechka, David Randall, Ken James, Ken Leslie, Betty Shankland, May Tucker, Mrs. John Lane and Junior Birders Steven and Martin McFarlane, David Senchuk, Peter and Stephen Kines, Sean Black and David Voorhis. 